\title{
Pelatihan kompetensi literasi digital bagi guru bahasa inggris berbasis e-learning moodle
}

\author{
Nadiah Ma'mun*, Siti Mariam \\ Universitas Islam Negeri Walisongo Semarang, Semarang \\ nadiah_makmun@walisongo.ac.id
}

\begin{abstract}
In the era of the COVID-19 epidemic that is currently sweeping the entire world, the teaching and learning process at every level of education must continue. Various learning methods and tools are used both offline and online. Online learning is still limited and must adhere to strict health protocols. Meanwhile, online learning is a solution to this situation. Many online media can be used, for example, Google Classroom, WA group, Zoom, Cisco Webex, Google Duo, and others. This community service aims to help teachers improve their skills in using the Moodle application.. It's currently considered the most fully-featured application for online (distance) learning. During the activation process, starting from the socialization process to training, the teachers were very interested in this activity, this was evidenced by the number of invited participants who all came. Participants attended the training from beginning to end, participants actively participated in the training and there were many questions and complaints submitted by the Teacher. After the training, participants implemented the use of the Moodle application in learning English online. Some teachers practice making teaching materials, online discussions, quizzes, and assignments while teaching, while asking questions and motivating students.
\end{abstract}

Keywords: Moodle application version 3.9; learning evaluation; MTs teacher; English learning; online learning

\begin{abstract}
Abstrak
Di era wabah COVID-19 yang melanda seluruh dunia saat ini, proses belajar mengajar di setiap tingkat pendidikan harus tetap berjalan. Aneka metode dan sarana pembelajaran digunakan baik off line maupun online. Adapun pembelajaran secara online masih terbatas dan harus tetap mengikuti protokol kesehatan yang ketat. Sedangkan pembelajaran online (daring) menjadi solusi dari keadaan ini. Ada banyak media daring yang dapat digunakan, misalnya google classroom, WA group, Zoom, Cisco webex, google duo, dan yang lainnya. Tujuan pengabdian ini untuk membantu para guru meningkatkan ketrampilan dalam pemakaian aplikasi moodle. Aplikasi ini adalah aplikasi yang dianggap paling lengkap fiturnya untuk pembelajaran daring (jarak jauh). Selama proses kegiatan, mulai dari proses sosialisasi hingga pelatihan, para Guru sangat tertarik pada kegiatan ini, hal ini dibuktikan dengan jumlah peserta yang diundang semuanya dating. Peserta mengikuti pelatihan dari awal hingga akhir, peserta aktif mengikuti pelatihan dan banyak pertanyaan juga keluhan yang disampaikan oleh Guru. Setelah pelatihan, peserta menerapkan penggunaan aplikasi Moodle dalam pembelajaran bahasa Inggris secara daring. Beberapa Guru menerapkan mempraktekan membuat bahan ajar, diskusi online, Quiz dan Assignment pada saat mengajar, pada saat memberikan pertanyaan dan memotivasi siswa.
\end{abstract}

Kata Kunci: aplikasi moodle versi 3.9; evaluasi pembelajaran; guru MTS; pembelajaran bahasa inggris; pembelajaran online 


\section{PENDAHULUAN}

Pembelajaran di masa pandemic ini mengubah pembelajaran tatap muka menjadi pembelajaran daring. Namun masih banyak kekurangan yang dirasakan baik oleh guru mau pun siswa. Adanya virus covid-19 pada tahun 2020 memberikan dampak yang luar biasa hampir pada semua bidang, salah satunya pada bidang pendidikan. Dengan adanya virus covid-19 ini membuat proses pembelajaran menjadi pembelajaran jarak jauh, tetapi dalam keadaan seperti ini pun guru masih tetap harus melaksanakan kewajibannya sebagai pengajar, dimana guru harus memastikan siswa dapat memperoleh informasi/ ilmu pengetahuan untuk diberikan kepada siswa.

Pembelajaran online ini dimulai tanggal 16 Maret 2020, dimana anak mulai belajar dari rumahnya masing-masing tanpa perlu pergi ke sekolah. Dalam Pembelajaran online diperlukan ilmu teknologi bagi seorang guru agar pembelajaran online tetap berjalan dengan efektif disaat pandemic seperti ini.

Guru harus melakukan inovasi dalam pembelajaran diantaranya dengan memanfaatkan teknologi dalam pembelajaran. Semenjak pembelajaran diberlakukan dirumah, sebagian guru melakukan pembelajaran lewat media online seperti Whatsapp, google meet, google classroom, dll. Berbagai inovasi dapat dilakukan guru dalam menyampaikan materi pembelajaran. Salah satunya ada yang menggunakan Whatsapp Group, dimana guru sebelumnya akan membuat video pembelajaran lalu dikirim kegrup untuk diamati oleh para siswa.

Kementerian Pendidikan dan Kebudayaan memiliki program yang ditujukan pada para siswa siswi jenjang TK/PAUD, Sekolah Dasar, Sekolah Menengah Pertama, dan Sekolah Menengah Atas. Ini merupakan upaya dalam terselenggaranya pendidikan bagi semua kalangan dimasa pandemik. Khususnya membantu masyarakat yang memiliki keterbatasan pada akses internet, secara ekonomi maupun lokasi rumah."Belajar dari TV seru, tapi kadang suka kurang ngerti apa yang lagi dijelasin". Imbuh seorang siswa SD yang mengikuti program belajar lewat stasiun TVRI.

Pembelajaran dapat dikatakan sebagai proses interaksi peserta didik dengan pendidik dan sumber belajar pada suatu lingkungan belajar. Ketika program TV ditayangkan sesuai dengan jenjangnya interaksi yang terjadi hanya satu arah, saat guru menjelaskan dan peserta didik mengamati siaran TV. Sehingga akan besar kemungkinan terjadinya miskonsepsi. Maka dari itu, perlu bimbingan dan arahan agar interaksi dua arah terjalin dan menghindari miskonsepsi.

Point penting yang juga ditekankan perihal penilaian yang diberikan guru kepada siswa, menegaskan disuatu pandemik sekarang penilaian harus diberikan guru lebih mengarah kepersoalan kualitas, bukan kuantitas.Jadi tugas-tugas itu tidak bias dinilai seperti biasa, tapi harus lebih bias memberikan motivasi. 
Pandemic covid-19 ini telah memberikan kita begitu banyak pelajaran, tidak hanya tentang upaya memutuskan rantai penularannya, tapi juga bagaimana sekolah-sekolah bereaksi memanfaatkan teknologi dalam proses belajar mengajar. Sejak dikeluarkannya instruksi oleh pemerintah terkait pencegahan virus corona, salah satunya dengan menghindari berada dikerumunan dan menjaga kebersihan serta kesehatan tubuh. Gubernur, Bupati, Walikota, Kementerian Pendidikan dan Kebudayaan bersama sama menginstruksikan kepadasekolah dan perguruan tinggi untuk melakukan pembelajaran daring.

Penelitian yang dikeluarkan oleh Pavlik, 2011 dan Center for Applied Special Technology (CAST) merekomendasikan pembelajaran online sebagai media pendidikan yang memberikan dampak positif terhadap hasil belajar peserta didik.Pembelajaran Online adalah belajar mengubah seseorang menjadi cerdas bukan sekedar pintar, yang digambarkan dengan smart people know from repetition of others, intelligent people can figure it out by themselves.

Karakter peserta E-Learning mengarah pada kegemaran belajar dan melakukan kajian pengembangan diri. Kondisi peserta E-Learning adalah mereka yang membutuhkan materi pelajaran tanpa meninggalkan rumah. Ekspektasi dengan pembelajaran online memang untuk memberikan kemasan pembelajaran yang sesuai dengan tujuan instruksional. Mode seluruh bahan ajar, diskusi, konsultasi, penugasan, latihan, ujian dilakukan secara online tanpa harus tatap muka antara pengajar dan peserta didik.Namun konsep pembelajaran menuju pendidikan secara komperehensif masih dipertanyakan sebagian masyarakat yaitu dari sisi afektif dan psikomotorik. Secara harfiah syarat personal pengajar adalah harus dapat berinteraksi dengan baik dan lebih personal terhadap peserta didik dengan memperhatikan kemajuan peserta didik, dan membantu persoalan peserta didik yang dihadapi.

Desain E-Learning yang menarik dan diminati menjadi penting untuk diperhatikan, menurut Onno W.Purbo (2012) merancang E-Learning setidaknya mampu memenuhi, sederhana, personal dan cepat. Sederhana dalam artian peserta didik mengenal dan memeiliki jenis aplikasi yang digunakan.Secara personal terdapat interaksi sebagaimana layaknya suasana di dalam kelas, kemudian layanan yang ditunjang dengan kecepatan memberikan respon terhadap keluhan dan kebutuhan peserta didik lainnya.

Kondisi pandemi wabah corona yang terjadi di Indonesia pada bulan Maret sampai saat ini 2020 mengisyaratkan kita pada proses pendidikan masa mudah diakses depan dengan jaringan yang terpadu terkait pada produktifitas tepat waktu, pluralistis, lebih dialogis, lebih terbuka, dan ini adalah gambaran pendidikan yang lebih luwes, terbuka dan beraneka ragam dijangkau oleh siapapun.

Berdasarkan isu permasalahan diatas, dan alasan memilih dampingan, maka dapat dirumuskan permasalahan utama yang akan dicari solusi nyatanya. Beberapa poin 
permasalahan tersebut yaitu (1) Para guru MTs kurang mendapat perhatian, masih kurangnya pelatihan yang diberikan terutama guru swasta tentang bagaimana guru dapat memakai media digital dalam pembelajaran bahasa dan evaluasinya untuk meningkatkan kompetensi pedagogi guru bahasa inggris MTs di Kota Semarang, (2) Belum adanya pelatihan mendesain pembelajaran berbasis Moodle (e-learning) dan mengevaluasi hasil pembelajaran lebih mudah dan efektif bagi guru-guru MTs.

Tujuan pengabdian kepada masyarakat $(\mathrm{PkM})$ yang dilakukan ini yaitu Menjelaskan, membekali dan memberikan pendampingan implementasi media digitaldalam pembelajaran bahasa dan evaluasinya untuk meningkatkan kompetensi pedagogi guru bahasa inggris MTs di Kota Semarang, (2) Menjelaskan literasi penggunaan media digital yang dapat diakses secara mudah pada pembelajaran bahasa dan evaluasinya di era revolusi industri 4.0.

Dengan diadakannya workshop dan pendampingan pemakaian media digital bagi Guru MTs di Kota Semarang memperoleh manfaat (target output) dari kegiatan ini adalah;

1. Untuk meningkatkan kompetensi pedagogi guru bahasa Inggris MTs dalam pemakaian media digital dalam pembelajaran bahasa dan evaluasinya di era revolusi industry 4.0 .

2. Untuk menfasilitasi pembelajaran siswa melalui pemanfatan media digital untuk mempermudah penguasaan materi yang diharapkan.

3. Untuk melatih kemandirian siswa dalam menemukan sumber sumber belajar sehingga pembelajaran mandiri (autonomous learning) dapat tercapai.

4. Untuk membuat pembelajaran lebih menyenangkan dan memberikan literasi pemanfatan media digital kepada siswa.

5. Guru dapat memanfaatkan, mendesain Pembelajaran berbasis Moodle versi terbaru (versi 3.9) dalam pembelajaran di Masa Pandemi Covid-19, dan Guru dapat Mengevaluasi hasil pembelajaran lebih mudah dan efektif .

\section{METODE PELAKSANAAN}

\subsection{Metode Yang Digunakan Dan Evaluasi}

Metode yang digunakan dalam pelaksanaan $\mathrm{PkM}$ ini adalah ceramah, praktik, kerja kelompok, diskusi dan evaluasi. Workshop praktek langsung dan pendampingan serta follow up mengenai strategi-strategi dengan menggunakan digital education tools untuk pembelajaran bahasa dan evaluasinya pada guru bahasa Inggris MTs di Kota Semarang.

Dalam pelatihan ini para guru MTs dilatih, didampingi oleh Narsum dan penulis selaku pelaksana pengabdian, bagaimana memanfaatkan Moodle dalam pembelajaran di Masa Pandemi Covid-19. Kegiatan pengabdian masyarakat yang berupa program pelatihan (workshop pelatihan pemakain moodle) ini telah dilaksanakan pada hari Kamis 16 Juli 2020 secara off line dengan mengikuti protokol kesehatan selama 6 jam (teori $30 \%$ dan 
praktek $70 \%$ ) dan diikuti pembimbingan praktek secara on line juga pendampingan di kelas virtual Moodle versi terbaru 3.9 selama seminggu.

Kegiatan pendampingan ini bertujuan agar para guru MTs mampu mempraktikan dan terampil dalam pemakain Moodle dilaksankan secara off line dan online dari 12 Juli 30 Juli di merinad.com, kelas Pelatihan Moodle. Peserta mendapatkan bantuan kuota data dan sertifikat bagi yang menyelesaikan seluruh sesi.

Di mulai dari awal Juli dimana dipilihkan aplikasi yang sesuai yang tepat sasaran dan efektif untuk para guru yaitu Moodle versi terbaru 3.9 oleh Bapak DR selaku narsum (nara sumber) pakar IT telah membeli domain home Moodle tersebut untuk digunakan dengan semaksimal mungkin bagi para guru selama satu tahun kedepan, domain tersebut diberi nama merinad.com. Kemudian di rancang disain secara lengkap mulai dari dibuatkan user name beserta password juga kelas bagi masing-masing peserta, lalu para peserta mulai log in ke Aplikasi yang sudah siap digunakan. Setelah para peserta login, pada tanggal 12 Juli dimulai pengenalan platform Moodle, pengenalan dan praktik pengisian fitur Moodle versi 3.9 secara on line. Selanjutnya pada tanggal 16 Juli secara off line para peserta mendapat penjelasan langsung dari narsum dan kemudian dialnjutkan demonstrasi dan unjuk kerja materi-materi pembelajaran dengan didampingi tim panitia pelaksana pengabdian pada workshop mulai jam 08.00 hingga 15.00 di Hotel Front One dengan tetap menjalankan protokol kesehatan.

\subsection{Metode Evaluasi Pelatihan}

Evaluasi atau competency assesment terkait dengan kemampuan awal guru dalam pembelajaran daring. Pelatihan memberikan kompetensi fungsional para guru MTs. Kompetensi fungsional memiliki tingkatan-tingkatan, basic (1), intermediate (2), advance (3) dan, expert (4). Ada empat level evaluasi terhadap keberhasilan sebuah pelatihan. Level 1. reaction, 2. learning, 3. behaviour appllication, dan 4. bussines impact. Level pertama adalah evaluasi reaksi peserta terhadap program yang diberikan. Apakah mereka mereka menyukai program ini? Apakah mereka merasa program ini bermanfaat?. Level kedua, menguji peserta pelatihan untuk menentukan apakah mereka telah mempelajari prinsip, ketrampilan, dan pengetahuan yang telah mereka pelajari. Level 3. menanyakan perilaku peserta pelatihan berubah karena program pelatihan. Sebagai contoh apakah karyawan di departemen pengaduan toko lebih sopan daripada sebelumnya dalam menerima ketidakpuasan pelanggan?. Level 4. bussiness impact. Apakah dampak pelatihan terhadap kinerja bisnis? Apakah terjadi penurunan jumlah keluhan pelanggan? Apakah jumlah penjualan meningkat? Apakah jumlah cacat mutu menurun, dan sebagainya.

Perubahan perilaku guru dalam menggunakan teknologi daring dapat dilihat dari perubahan dalam menggunakan media pembelajaran. Ranah (kognitif, afektif, dan psikomotorik) sebagaimana Bloom dapat dipergunakan sebagai dasar untuk mengarahkan pada terjadinya perubahan perilaku sesuai yang diharapkan dalam tujuan pelatihan ini. Ada beberapa indikator yang dapat digunakan untuk mengukur 
keberhasilan sebuah training atau pelatihan : baik dari segi Indikator performa dan Indikator kinerja.

Menurut hasil kajian Broad and Newstrom (1992) menunjukkan bahwa kurang dari $30 \%$ dari apa yang diajarkan dalam training dapat ditransfer dalam pekerjaan seharihari dan memberikan dampak bagi peningkatan kinerja.

\subsection{Target Output}

Pada awal program untuk membangun kedekatan secara individu antara pengabdi dan mitra dampingan, perkenalan secara umum telah dilakukan pada pra-pelaksanaan pendampingan yaitu pada saat penelitian pendahuluan. Pengabdi langsung turun langsung ke lapangan untuk mewawancara calon mitra dampingan. Mitra dampingan yang berhasil ditemui untuk menjadi responden penelitian pendahuluan adalah sebanyak 5 guru MTs.

Media yang digunakan dalam pelatihan adalah presentasi powerpoint, makalah, serta tayangan aplikasi moodle. Para guru diberi kesempatan untuk praktek bermain peran. narasumber pelatihan ini adalah Bapak DR.

\section{Tahap Persiapan}

Kegiatan sosialisasi ini dilakukan dengan memperkenalkan program sekaligus menjajaki target dan jumlah audien/peserta yang akan di tuju serta memilih media yang paling sesuai. Tentunya, target utama dari sosialisasi ini adalah untuk memudahkan masyarakat memahami pesan yang disampaikan. Maka, kegiatan sosialisasi ini harus direncanakan dan dilaksanakan dengan seksama dan terprogram untuk memastikan kegiatan yang dilaksanakan dapat berjalan sesuai dengan yang diharapkan. Tujuan dari pelaksanaan Sosialisasi ini adalah untuk memberikan gambaran (overview) tentang kegiatan pengabdian yang akan dilaksanakan. Selain itu, juga untuk meminta ijin untuk melaksanakan rangkaian kegiatan Pengabdian pada Masyarakat yang terdiri dari dua (2) kegiatan utama, yaitu dalam bentuk Pelatihan guru-guru MTS dan dilanjutkan dengan kegiatan Pendampingan para guru tersebut. Lebih lanjut lagi, kegiatan sosialisasi ini sekaligis untuk menentukan tanggal pelaksanaan pelatihan yang diikuti pembimbingan praktek.

Sosialisasi kegiatan program pengabdian pada masyarakat dengan judul: "Workshop Pelatihan Pemakaian Moodle di Era Covid 19"dimulai sejak awal Juli dimana dipilihkan aplikasi yang sesuai yang tepat sasaran dan efektif untuk para guru yaitu Moodle versi terbaru 3.9. Narsum pakar IT telah membeli domain home Moodle tersebut untuk digunakan dengan semaksimal mungkin bagi para guru selama satu tahun kedepan, domain tersebut diberi nama http://merinad.com. Kemudian setelah dibuatkan lengkap user name beserta password juga kelas bagi masing-masing siswa oleh narsum, para peserta mulai log in pada tanggal 12 Juli 2020 dan para peserta bisa konsultasi langsung ke narsum baik via Moodle yang sudah disediakan juga WA group 
untuh lebih memudahkan komunikasi dan koordinasi. Peserta dari Guru-Guru MTs di Kota Semarang yang berjumlah 16 sudah bisa memulai pembelajarn secara on line pada tanggal 12 Juli 2020 dimulai dari pengantar Moodle (http://merinad.com (tampilan Moodle)).

\section{Pendampingan}

Pendampingan berupa menerima pertanyaan dan keluhan guru dalam aplikasinya, serta memberikan solusi sesuai dengan permasalahan yang dihadapi.

\subsection{Khalayak Sasaran}

Program pelatihan dan pendampingan ini diperuntukkan untuk guru-guru bahasa inggris MTs di kabupaten semarang. Guru-guru tersebut jadi sasaran pelatihan ini, karena masih sedikit yang mendapatkan pelatihan dan pendampingan dalam pembelajaran daring pada saat pandemi covid-19 ini. Oleh karena itu, tim pengabdi, tergerak untuk melaksanakan pengabdian ini guna membantu para guru bahasa Inggris MTs supaya tetap dapat melaksanakan proses pembelajaran secara maksimal dengan memanfaatkan teknologi daring yang cukup efektif, dan mudah digunakan.

Pertama-tama peserta pelatihan dapat mengubah identitasnya di menu (fitur) edit profile dengan berbagai informasi pribadi, misalnya nama, alamat email, kota, gambar pribadi, atau informasi lainnya. Saat mengupload gambar (foto), maka digunakan ukuran file yang kecil saja,yakni kurang dari 10 KB. Login terlebih dahulu ke Moodle http://merinad.com.Kemudian di sebelah kanan atas ada nama dari masing-masing perserta, lalu mulai mengubah profil, dengan meng klik nama peserta tersebut.

Langkah selanjutnya, pengguna (pengajar) dengan status sudah menjadi course creator dapat membuat course baru. Pengguna dapat memasukkan berbagai materi pembelajaran melalui pengaturan setting course. Untuk memulai mengedit coursememasukkan materi dan kegiatan pembelajaran, dengan meng klik tombol "Turn editing on", sehingga tampilan suatu course tombol tersebutsudahberupa berubah menjadi "Turn editing off" berarti halamansiap untuk diedit satu persatu mulai dari topik, materi pembelajaran dan lain sebagainya yang dibutuhkan dalam mata pelajaran tersebut. Selanjutnyapengajar juga dapat memasukkan berbagai materi pembelajaran melalui menu “Add a resource...", berbagai jenis resources dapat dimasukkan.

Proses pemasukkan materi akan lebih cepat yaitu dengan menggunakan menu "Link ke file atau situs web". File-file tersebut dapat langsung diupload ke server. Materi dapat juga berasal dari situs web tertentu. Untuk judul materi pembelajaran harus dituliskan, sedangkan ringkasannya bersifat opsional.Untuk memilih file yang akan dimasukkan,klik tombol "Choose or upload a file...", Kemudian pengajar mencari file yang akan diupload dengan menekan tombol "Browse",kemudian setelah filenya 
dipilih,tekan tombol "Upload this file".Dengan demikian file akan terupload ke server dan siap dimasukkan kehalaman course.

\section{HASIL DAN PEMBAHASAN}

Berdasarkan wawancara, tanya jawab dan pengamatan langsung selama kegiatan berlangsung, kegiatan pengabdian pada Guru MTs ini memberikan hasil sebagai berikut:

\subsection{Faktor Pendukung dan Penghambat}

Beberapa faktor yang mendukung terlaksananya kegiatan pengabdian pada masyarakat ini adalah dukungan dari universitas, Besarnya minat dan antusiasme peserta dalam kegiatan, sehingga kegiatan berlangsung dengan lancar dan efektif, yaitu dapat dilihat dari respon dan interaksi peserta pada trainer juga interaksi antar peserta. Selain itu dukungan dari stake holder;

1. Para Guru memberi dukungan dengan antusias menjadi peserta.

2. Faktor pendukung lainnya yaitu komunikasi yang baik dan kerjasama yang baik yang sangat menentukan keberhasilan dari PkM

Selama proses kegiatan, mulai dari proses sosialisasi hingga pelatihan, para Guru sangat tertarik pada kegiatan ini, hal ini dibuktikan dengan jumlah peserta yang diundang semuanya datang, peserta mengikuti pelatihan dari awal hingga akhir peserta aktif mengikuti pelatihan dan banyak pertanyaan juga keluhan yang disampaikan oleh Guru. Peserta antusias dalam pembimbingan praktek mengajar. Setelah pelatihan, peserta menerapkan penggunaan aplikasi Moodle dalam pembelajaran bahasa Inggris secara daring Beberapa Guru menerapkan mempraktekan membuat Bahan Ajar, Diskusi Online, Quiz dan Assignment pada saat mengajar, pada saat memberikan pertanyaan dan memotivasi siswa.

Sedangkan faktor penghambatnya adalah keterbatasan waktu soialisasi, pelatihan dan pendampingan secara off line dikarenakan di Masa Pandemi. Para peserta akan lebih semangat dan full powerful, full energy apabila kegiatan pelatihan diadakan secara off line. Namun dapat diatasi pendampingan secara on line baik via WA group dan dengan memutar ulang video-video tutorial lengkap yang diberikan oleh Narsum. Serta adanya kendala koneksi internet yang kurang memadai.

\subsection{Evaluasi Hasil Pelatihan}

Evaluasi dalam pelatihan ini dilaksanakan dengan teknik behavior application (perubahan perilaku). Teknik tersebut digunakan untuk mengukur kompetensi ranah kognitif, afektif, dan psikologis. Dari 16 peserta pelatihan, yakni para guru bahasa Inggris MTs, didapatkan hasil bahwa mayoritas mereka mengakui bahwa pelatihan mendesain pembelajaran dengan moodle sangat efektif untuk pembelajaran bahasa 
Inggris, hanya saja masih ada kendala terkait dengan siswa yang belum memiliki akses internet baik karena orang tuanya tidak mampu atau lembaganya yang belum menyediakan akses. Adapun terkait dengan fitur dalam aplikasi moodle versi 3.9 yang sering dipakai oleh para guru fitur diskusi online dan quiz, input soal ulangan, sedangkan penggunaan video kongrea masih jarang dilakukan karena para siswa masih terkendala aksesnya. Mengenai kesulitan dalam pemakaian aplikasi moodle para responden mengakui kesulitan karena tidak semua web browser dapat support dengan aplikasi moodle, begitu juga kendala dalam membuat embedded answer tanpa multiple choice

Mengenai cara mengatasi kesulitan tersebut, responden mengakui bahwa mereka dapat mengakses video tutorial pemakaian model. Tetapi ada yang menjawab bahwa selama pandemik tidak menggunakan aplikasi ini, hal itu disebabkan pembelajaran di pondok khususnya masih menggunakan luring atau tatap muka langsung. Selnajutnya terkait dengan keunggulan dan keterbatasan aplikasi ini, responden mengakui bahwa aplikasi ini menyidiakan vitur yang variatif terrutama untuk mengevaluasi siswa dengan quiz karena score bisa langsung diketahui. Hanya saja kelemahannya adalah terletak pada ketidakmampuan memberikan jawban alternative terhadapa soal ujian. Dari sisi dukungan institusi, responden mengakui ada sebagian yang mendukung penerapan aplikasi ini di sekolah, tetapi ada yang belum mampu menerapkan secara kelembagaan.

Dengan demikian, pemakaian aplikasi moodle dalam pembelajarani bahasa Inggris, sangat efektif, hanya masih terkendala dengan akses internet siswa, dan beberapa lembaga yang belum berminat dengan model daring moodle. Sebab penerpan system pembelajaran akan berjalan efektif jika ada dukungan dari lembaga tempat para guru mengajar.

\section{SIMPULAN}

Dari serangkaian kegiatan pengabdian yang dilakukan, dapat disimpulkan bahwa melalui program pengabdian masyarakat ini memberikan manfaat terhadap guru MTS. penggunaan Moodle ini efektif untuk pembelajaran Bahasa Inggris secara daring bagi siswa. Dengan aplikasi Moodle, guru dapat memantau keaktifan peserta didik, contohnya guru dapat melihat siapa saja yang sudah atau belum melihat materi yang telah disediakan. Moodle juga memberikan data siapa peserta didik yang tidak aktif mengikuti pelajaran. Selain itu memudahkan guru untuk memberikan evaluasi pembelajaran dengan menggunakan fitur quiz. Fiturfitur yang sering digunakan oleh para peserta guru MTs (berdasarkan hasil wawancara) dalam aplikasi Moodle versi 3.9 antara lain menggunakan fitur book untuk menyediakan materi, forum untuk berdiskusi, dan quiz untuk mengevaluasi pembelajaran. Guru terampil dan familiar menguunakan fitur-fitur tersebut secara optimal. Namun saat menggunakan fitur; congrea, belum maksimal, belum berhasil. Untuk mengatasi hal tersebut peserta membuka video tutorial dari pemateri. 
Peserta juga selain memahami dan terampil dalam melakukan Evaluasi terhadap siswa melalui aplikasi Moodle yakni dengan menggunakan fitur Quiz seperti multiple choices dan embedded answer serta merekap keaktifan siswa pada menu notification.

Adapun kesulitan atau kendala yang dialami siswa dalam menggunakan aplikasi Moodle selama pembelajaran Bahasa Inggris secara daringadalah saat pertama login menggunakan username dan password mereka. Juga saat mengikuti diskusi online dan quiz pada kali pertama. Namun, kendala tersebut dapat diatasi dengan memberikan video tutorial dan seiring berjalannya waktu, mereka mulai terbiasa menggunakan Moodle.

Guru dapat memantau siapa saja peserta didik yang aktif mengikuti pembelajaran selama PJJ, guru mudah melakukan evaluasi menggunakan fitur quiz, materi tersimpan dengan rapih dan dapat dibuka kapanpun. Keterbatasannya, peserta didik yang akan mengumpulkan tugas berupa foto atau video harus menggunakan link.

\section{REKOMENDASI}

Program pelatihan pemakaian moodle dalam pembelajaran bahasa inggris dan evaluasinya bagi guru MTs Di Kabupaten Semarang berupa pendampingan guru MTs dalam mengajar ini secara umum telah berjalan lancar, namun masih memerlukan pengembangan dan follow-up agar pelaksanaannya lebih optimal. Berikut beberapa rekomendasi pengembangan program lebih lanjut :

1. Pendekatan secara individu masing-masing obyek dampingan perlu dilakukan lebih intensif agar obyek dampingan benar-benar merasa diberdayakan dan mendapatkan manfaat dari program ini.

2. Guru MTs masih memerlukan pelatihan yang khusus. Direkomendasikan bagi program-program selanjutnya untuk lebih banyak dalam pembahasan mengenai silabus dan bahan ajar tentang pemakaian media digital dalam pembelajaran Bahasa Inggris dan evaluasinya.

Setelah mengikuti pelatihan ini, para guru harus tetap mengasah dan melatih kemampuannya, agar bertambah trampil dan profesional dalam pemakaian aplikasi Moodle maupun aplikasi-aplikasi lainnya. Pelatihan ini akan kita lakukan terusmenerus untuk menunjangprofesionalisme dosen dan Guru.

\section{REFERENSI}

Adler, C.,R. (2019). Seven Strategies to Teach Students Text Comprehension //www.readingrockets.org.Diakses 11 Agustus 2019

Alyousef, Hesham Suleiman. (2006). Teaching Reading Comprehension to ESL/EFL Learners. Journal of Language and Learning Volume 5 Number I.

Batubara H. (2018). Pembelajaran Web Berbasis Dengan Moodle Versi 3.4. CV Budi Utama

Beers,S.Z. (2012). 21st Century Skill: Preparing Students for Their Future. 
Biancarosa, Gina. (2012). Technology Tools to Support Reading in the Digital Age.https://www.researchgate.net/publication/232233753.

Carmen M , Magdalena L., P. (2017). ICT in the English Classroom.Qualitative Analysis of the Attitudes of Teachers of English towards Its Implementation in Secondary Schools. 7th International Conference on Intercultural Education "Education, Health and ICT for a Transcultural World”.EDUHEM , Almeria, Spain.

Lestari, I., W, M.Hum. (2016). Peningkatan Kemampuan Berpidato dalam Bahasa Inggris untuk Siswa Tingkat SMA di Sekolah-Sekolah Muhammadiyah Yogyakarta.Laporan Pengabdian Kepada Masyarakat.Universitas Muhammadiyah Yogyakarta.

Lihawa, K. (2015). Meningkatkan Kemampuan Berbicara Bahasa Inggris dalam Percakapan Sehari-hari Bagi Para Pemuda di Kabupaten Gorontalo Utara. Laporan Pengabdian Kepada Masyarakat. Universitas Negeri Gorontalo.

Nash S, \& Rice W. (2018). Fourth Edition. Moodle E Learning Course Development. Packt Publishing. Birmingham, Mumbai

Pramesworo, I,.S. (2016). Peningkatan Kemampuan Berbahasa Inggris Anak-anak Panti Asuhan Panti Yatim Indonesia. Laporan Pengabdian Kepada Masyarakat. http://dosen.perbanas.id.

Sinsuw E, \& Sambul A.,M. (2015). Pelatihan Pengembangan Media Pembelajaran Berbasis ICT sebagai Sumber Pembelajaran bagi guru-guru SMP/MTs/SMA di Kecamatan Ngambur Pesisir Barat.Jurnal Teknik Elektro dan Komputer. Teknik Informatika, Universitas Sam Ratulangi, Manado, Indonesia, vol 6 no 3, ISSN : 2301-8402. 